\title{
Publication ethics: science versus commerce
}

\author{
Henk ten Have ${ }^{1} \cdot$ Bert Gordijn $^{2}$
}

Published online: 11 April 2017

(C) Springer Science+Business Media Dordrecht 2017

One of our students submitted a manuscript to the International Journal of Philosophy and Theology. This is a prestigious peer-reviewed journal, founded in 1938 by Jesuit Academics at the University of Louvain in Belgium. Initially a Dutch language journal, Bijdragen, it was internationalized in 2013 and is now published by Taylor and Francis (http://www.tandfonline.com/toc/rjpt20/current). Within a few weeks our student received a message from the journal that his contribution had been reviewed and accepted: the topic was relevant, the methodology sound, and the relevant literature engaged. His manuscript could be published rather quickly. As soon as the publication had materialized, the student received an invoice of $\$ 200$ to be paid to a bank account in Bangladesh. Another student who had presented a paper during a conference in Cyprus told us that immediately after the conference she received an email from the Journal of Clinical Research and Bioethics (https://www.omicsonline.org/clinical-research-bioethics. php) inviting her to submit the text of her presentation. She was of course flattered, and in her innocence she had submitted her text. We advised her to withdraw the manuscript as soon as possible, but in that case she might face a retraction fee.

\section{Predatory and hijacked journals}

These kinds of stories are happening often, especially to students and junior researchers. It emphasizes the need to
Henk ten Have
tenhaveh@duq.edu
1 Duquesne University, Pittsburgh, USA
2 Dublin City University, Dublin, Ireland

pay more attention to what is currently going on in science, research, and publishing. In this issue Eriksson and Helgesson (2017) refer to the "False academy." Fraudsters are operating everywhere and at all stages of scientific research. In these times of 'fake news' and 'alternative facts', you can as a scientist no longer trust your 'colleagues.' They refer to the phenomenon of "predatory journals." This is one of the hot topics of the moment in science and publishing (Beall 2017, 2016; Shamseer et al. 2017; Singer 2017; Carroll 2016; Danevska et al. 2016; Gasparyan et al. 2016; Dadkhah and Bianciardi 2016; Shen and Björk 2015). Editors and commentators have called this recent phenomenon "an emerging threat to the medical literature" (Harvey and Weinstein 2017), "the worst thing in publishing, ever" (Cook 2017), "another nail in the coffin of academics" (Kumar and Saxena 2016), or simply "academic nightmares" (Van Nuland and Rogers 2016).

As illustrated in this issue, it is not always easy to distinguish predatory and legitimate journals. Predatory journals are characterized by a very weak or absent peer review process in combination with publication fees. They heavily spam potential authors. All us are receiving frequent invitations to contribute manuscripts or join editorial boards. On their websites there is insufficient contact information. The listing of editorial boards is incomplete. The major focus is on quick publication without serious review after payment of a fee (Van Nuland and Rogers 2016; Danevska et al. 2016; Gasparyan et al. 2016). The business model is "pay and publish". The result is "bogus research" (Dadkhah and Bianciardi 2016). This is the real danger of predatory publishing: these publications pollute the pool of scientific knowledge. They are for example included in databases such as PubMed (Harvey and Weinstein 2017). Bypassing the traditional peer-review process they produce weak, unreliable and questionable knowledge (Cook 2017). 
Our first student did not know-and neither did wethat there are in fact two journals with the same name International Journal of Philosophy and Theology: http:// www.tandfonline.com/toc/rjpt20/current and http://ijptnet.com/. The last one refers to a fancy website with an impressive name: American Research Institute for Policy Development (http://aripd.org/). This organization publishes 52 journals in areas such as Arts, Humanities and Social Science, as well as Science and Technology. The journals have fancy names, often identifying an international scope. The fact that the journal has exactly the same name as a known, prestigious journal is of course deceptive. It is known as "hijacking." Websites are created with the same name as respectable journals. The hijackers than approach target groups with spam email (Dadkhah et al. 2016, 2017; Beall 2016; Danevska et al. 2016; Shen and Björk 2015). As Eriksson and Helgesson explain, the business model of these hijacked journals is the same as for predatory journals. The operators are not interested in your data or research: your wallet is the primary target (Eriksson and Helgesson 2016, 2017). Their websites are misleading visitors to assume that it represents a reputable journal (Dadkhah et al. 2016). Many young scholars have had bad experiences with the above-mentioned Institute: they submitted manuscripts that were quickly accepted, then paid the fee but their manuscript was never published (https:// www.researchgate.net/post/What_would_you_do_if_a journal_did_not_publish_your_manuscript_in_the_scheduled_time).

\section{Reliable and unreliable journals}

The second student was the victim of aggressive spamming. We all receive frequently messages like these from all different types of journals. Most of us delete these messages immediately knowing that we are not Nobel Laureates who exceptionally have the honor to be invited to write for a journal. Students should learn that not only you have to check the status of a journal but also that you as a scientists have to decide what type of journal you are considering for publication of your work. Eriksson and Helgesson in their Ethics Blog provide an excellent overview of reliable journals in bioethics. They recommend where to publish. They also have a list of unreliable journals (Eriksson and Helgesson 2016). Some argue that it will be important to develop a white list for example using MEDLINE (Beall 2017). Other authors take another approach. Instead of producing lists of journals, they argue that in these times of publication pressure scientists should know how to identify reliable journals and distinguish them from less reliable ones and even pseudojournals (Danevska et al. 2016; Shamseer et al. 2017).
Prior to making a decision where to submit a manuscript students should learn to check potential journals (Abbott 2017; Shahriari et al. 2016).

\section{Bioethics teaching}

Information about predatory and hijacked journals is available and should be included in bioethics teaching programs, as essential knowledge for bioethics students. However, one can wonder how long this information will still be available. One of the most well known lists of predatory journals, Beall's list, is now removed from the Internet without explanation (Watson 2017; Oransky and Marcus 2017). Created in 2008, Beall made in fact two lists, one of journals and another of questionable publishers. Both lists included several 1000 predatory journals and publishers. The lists were commonly used to check upon the status of a journal. Now the website reads: "service no longer available") (https://scholarlyoa.com). Publishers like OMICS International have threatened Beall for a long time, and presumably they have been successful now in blocking information about their practices (Oransky and Marcus 2017; New 2013). Somebody has also created a defamatory website about "predatory blogger" Jeffrey Beall (http://scholarlyoa.net/).

This issue includes two more articles that are relevant for publication ethics. Ekmekci (2017) argues that publication bias plays an important role in publishing. There is significant misconduct in disseminating knowledge. But there is also bias based on the presumed significance of results or positive expectations of effects. A major bias is that most publications are in English and that non-English publications are often excluded in databases and general reviews. Ekmekci (2017) also points out that a significant proportion of all publications is either duplicated or redundant.

The general problem of conflict of interests looms large over these adverse developments in publication ethics. This issue is addressed by Sperling (2017). A major approach in countering conflicts of interests, and especially financial payments of the industry, has been transparency. In the US all payments now have to be publicly notified according to the Sunshine Act, which is part of the Affordable Care Act. That is why we know that in 2014 the pharmaceutical and medical industry paid almost 6.5 billion USD to physicians and teaching hospitals. More than 400 million USD was paid for 'entertainment' (Sperling 2017). For this amount we could treat 400,000 HIV patients and save 13 million people from starvation. Transparency is an important fist step. But now that we know the empirical data, the normative question is what next? 


\section{References}

Abbott, J.H. 2017. How to choose where to publish your work. Journal of Orthopaedic and Sports Physical Therapy 47: 6-10.

Beall, J. 2016. Dangerous predatory publishers threaten medical research. Journal of Korean Medical Science 31: 1511-1513.

Beall, J. 2017. Predatory journals threaten the quality of published medical research. Journal of Orthopaedic and Sports Physical Therapy 47 (1): 3-5.

Carroll, C.W. 2016. Spotting the wolf in sheep's clothing: Predatory open access publications. The Journal of Graduate Medical Education 8 (5): 662-664.

Cook, C. 2017. Predatory journals: The worst thing in publishing, ever. Journal of Orthopaedic and Sports Physical Therapy 47 (1): $1-2$.

Dadkhah, M., and G. Bianciardi, 2016. Ranking predatory journals: Solve the problem instead of removing it! Advanced Pharmaceutical Bulletin 6 (1): 1-4.

Dadkhah, M., T. Maliszewski, and M.D. Jazi. 2016. Characteristics of hijacked journals and predatory publishers: Out observations in the academic world. Trends in Pharmacological Sciences 37 (6): 415-418.

Dadkhah, M., S.E.H. Seno, and G. Borchardt. 2017. Current and potential cyber attacks on medical journals: Guidelines for improving security. European Journal of Internal Medicine 38: $25-29$.

Danevska, L., M. Spiroski, D. Donev, N. Pop-Jordanova, and M. Polenakovic. 2016. How to recognize and avoid potential, possible, or probable predatory open-access publishers, standalone, and hijacked journals. Contributions, Section of Medical Sciences 37 (2-3): 5-13.

Ekmekci, P.E. 2017. An increasing problem in publication ethics: Publication bias and editors' role in avoiding it. Medicine, Health Care and Philosophy. doi:10.1007/s11019-017-9767-0

Eriksson, S., and G. Helgesson. 2016. Where to publish and not to publish in bioethics. The Ethics Blog. https://ethicsblog.crb.uu.se/2016/04/19/ where-to-publish-and-not-to-publish-in-bioethics/.

Eriksson, S., and G. Helgesson. 2017. The false academy: Predatory publishing in science and bioethics. Medicine, Health Care and Philosophy.
Gasparyan, A.Y., B. Nurmashev, A.A. Voronov, A.N. Gerasimov, A.M. Koroleva, and G.D. Kitas. 2016. The pressure to publish more and the scope of predatory publishing activities. Journal of Korean Medical Science 31: 1874-1878.

Harvey, H.B., and D.F. Weinstein. 2017. Predatory publishing: An emerging threat to the medical literature. Academic Medicine 92: $150-151$.

Kumar, P., and D. Saxena. 2016. Pandemic of publications and predatory journals: Another nail in the coffin of academics. Indian $J$ Community Medicine 41 (3): 169-171.

New, J. 2013. Publisher threatens to sue blogger for \$1-billion. The Chronicle of Higher Education. http://www.chronicle.com/ article/Publisher-Threatens-to-Sue/139243.

Oransky, I., and A. Marcus. 2017. A famed journal blacklist is dead. Long live a blacklist! https://www.statnews.com/2017/01/27/ journal-predatory-blacklist/.

Shahriari, N., J.M. Grant-Kels, and M.J. Payette. 2016. Predatory journals: How to recognize and avoid the threat of involvement with these unethical "publishers". Journal of the American Academy of Dermatology 75: 658-659.

Shamseer, L., D. Moher, O. Maduekwe, L. Turner, V. Barbour, R. Burch, J. Clark, J. Galipeau, J. Roberts, and B.J. Shea. 2017. Potential predatory and legitimate biomedical journals: Can you tell the difference? A cross-sectional comparison. BMC Medicine 15: 28. doi:10.1186/s12916-017-0785-9.

Shen, C., and B.-C. Björk. 2015. 'Predatory' open access: A longitudinal study of article volumes and market characteristics. BMC Medicine 13: 230. doi:10.1186/s12916-015-0469-2.

Singer, A. 2017. Not all young journals are predatory. The Western Journal of Emergency Medicine 18 (2): 318-321.

Sperling, D. 2017. (Re)disclosing physician financial interests: Rebuilding trust or making unreasonable burdens on physicians? Medicine, Health Care and Philosophy. doi:10.1007/ s11019-017-9751-8.

Van Nuland, S.E., and K.A. Rogers. 2016. Academic nightmares: Predatory publishing. Anatomical Sciences Education. doi:10.1002/ase.1671.

Watson, R. 2017. Beall's list of predatory open access journals: RIP. Nursing Open 4 (2): 60. 